\title{
Causes of Interreligious Conflict
}

\subsection{Introduction}

What are causes of conflict between religious groups? This chapter focuses on believers' perceptions of the causes of interreligious conflict. What do Christian, Muslim and Hindu students perceive as possible causes of religious conflict? What situations potentially contribute to religious conflict, according to these students? Perceptions of causes of conflict are not objective descriptions of facts. They are interpretations based on the (re)definition of the respondents' religious identity, on the (re)affirmation of the authority of their religious tradition, and most likely also reflect their circumstances in terms of level of anxiety and uncertainty (Sidel 2007, 1-17).

Often God as the ultimate reality and final authority is advanced as the motive for religious involvement in (destructive) conflict. The violent face of religion is evident in its politicization in nationalism, its radicalization as fundamentalism, and its instrumental use by terrorism. No religion is free from such ambiguous features, given the close link between religion and the economic, political and social domains. In India the three major religions have been, and in some cases continue to be, sources of violent conflict. Christianity's close link with those who colonized and dominated the Indian subcontinent in the latter half of the second millennium and the existence of contemporary Christian fundamentalist groups demonstrate the conflictive features of Christianity. Similarly, the spread of Islam through invasion and conquest since the 8th century CE and the present instrumentalization of Islam by terrorist groups in India reveal the conflictive side of Islam. And Hinduism, which in all its varied forms has inspired the vast majority of Indians over three millennia, was not totally free from violence. For example, the attacks by Saiva sects on the flourishing Jain and Buddhist communities in South India since the 7 th century ended with their disappearance from Tamil Nadu. Some Hindu fundamentalist groups are also responsible for sporadic violence on the Indian subcontinent today.

To gain empirical insight into the causes of religious conflict we proceed as follows. In section 7.2 we identify four types of causes of conflict between religious groups: economic, political, ethnic-cultural and religious causes. Section $7 \cdot 3$ presents the empirical research, starting with the research questions, fol-

(C) ANTHONY, HERMANS \& STERKENS, 2015 | DOI 10.1163/9789004270862_009

This is an open access chapter distributed under the terms of the Creative Commons AttributionNoncommercial 3.o Unported (CC-BY-NC 3.0) License 
lowed by the measuring instruments and our findings. In section 7.4 we summarize our findings and evaluate them from a normative perspective.

\subsection{Theoretical Framework: Realistic Conflict Group Theory Versus Social Identity Theory}

We distinguish between four types of causes that may lead to interreligious conflict. The first two are based on the conviction that conflict arises from competition for scarce resources like economic wealth or political power. The third and fourth types do not see such competition as a necessary condition, but consider group identification sufficient to cause conflictive relationships.

In so-called realistic conflict group theory hostility towards other groups is aimed at securing the means to attain the goals of one's own group. Rival interests of religious groups are considered the main reason for conflict. These interests can be material (e.g. land, water, money, labour) or non-material (e.g. power, status, values), but are clearly identifiable. Because intergroup conflict arises from competition for scarce material resources, power, status and differing values, they are regarded as rational and realistic (Coser 1956; Sherif 1967; Austin \& Worgel 1979; Brief et al. 2005). The competition can be actual or perceived, and may be limited to specific social strata in different religious groups. Actual competition, for instance, relates to disparities in average living standards, unemployment rates, discriminatory or affirmative action regarding appointments to public office, and population growth caused by migration. Dwindling resources coupled with sustained levels of competition (e.g. in economic crises) or increasing competition for stable available resources (e.g. because of migration) will trigger conflict if competition is interpreted on the lines of the groups involved (Coenders \& Scheepers 1998). But 'realistic' competition can also be a matter of perception, as when job opportunities and perceived living standards of one's family are considered to be lower than those of others, or when one thinks one has less access to education. Perceived competition is a major determinant of intergroup attitudes and behaviour (Esses 2002 et al.). In this study we distinguish between two types of 'realistic' causes of religious conflict: socio-economic and political.

Social identity theory, on the other hand, claims that competitive relations are not a necessary condition for intergroup conflict. Tajfel's (1981) minimal group experiments ('minimal' because there were neither conflicting interests nor a history of hostility between the groups) proved that group identification in itself is sufficient to lead to in-group favouritism and out-group discrimination. In social identity theory intergroup attitudes are explained in terms of the 
psychological processes of cognitive perception underlying group identification. Discourses on difference are always part of group identification. More specifically, social categorization, patterns of identification and contra-identification, and social comparison are socio-psychological processes underlying group formation that potentially provoke exclusionary reactions (cf. Sterkens 2007). In the previous chapter we explained these notions of social categorization, (contra-)identification and social comparison in some detail (cf. 6.2.).

Sidel $(2007,11 \mathrm{ff})$ confirms that the (re)definition of religious identity and the (re-)articulation of claims to religious authority can be seen as causes of religious conflict, especially in heightened states of uncertainty and anxiety. The latter qualification makes it clear that social identity theory must not be misunderstood as an unconditional theory that explains conflict independently of contextual factors. Although social identity theory stems from a critique of realistic group conflict theories, it does not dissociate itself from such approaches. Intergroup competition for actual and/or perceived scarce resources remains important. Competitive conditions intensify group identification and may affect intergroup relations (Jetten et al. 2001; Turner \& Reynolds 2003), in addition to factors like group size, power and status differences between groups, as well as specific histories of conflict. While group identification may entail conflictive relationships, conflict may also restore the religious identity of groups when it is threatened and may reclaim the authority of their own religion. It is the intertwinement of identity construction and group interests that sparks interreligious conflict, not (just) economic or political competition that develops arbitrarily on religious lines. Nevertheless the identity concern is usually manifested in the public domains of economic, political or socio-cultural life. In India, for instance, the link between national identity and Hinduism may be perceived as a threat to the identity of minority groups (Muslims and Christians). But some Hindus may see a loosening the link between national identity and religion as a threat to the definition of being Hindu. To summarize, in interreligious conflict both actual and perceived competition for material and non-material resources relates to group identification in different ways.

What types of causes of interreligious conflict do believers identify? In this research, we distinguish between four types: socio-economic, political, ethniccultural and religious causes. The first two types are based on realistic conflict group theory, the latter two on social identity theory. However, they overlap. In all four types of conflict violent actions are the means to (re)define religious identity and (re)claim the authority of one's own religion. At the same time these violent actions are justified by the ends. According to Hannah Arendt such means-end thinking typifies violent conflict: "The very substance of 
violent action is ruled by the means-end category, whose chief characteristic, if applied to human affairs, has always been that the end is in danger of being overwhelmed by the means which it justifies and which are needed to reach it" (Arendt 1970, 4).

\subsubsection{Socio-economic Causes of Interreligious Conflict}

Firstly, conflict between religious groups can have socio-economic dimensions. When one group (especially a minority group) is economically successful this is likely to lead to intolerance on the part of other, less successful groups (often majority groups). When groups are defined on religious lines economic tensions between them can easily turn into interreligious conflict. Economically disadvantaged groups can also be oppressed on the basis of religious convictions. The much contested role of the Hindu caste system is a clear example. On the other hand, religions can motivate their followers to engage in actions to change socio-economic conditions, such as access to jobs or equal wages for all irrespective of religious background. We refer to Weber's classical sociological studies $(1930 ; 1958)$, which explore the influence of religion on secular economic behaviour. While people's social and economic situation is perpetuated by diverse cultural factors, in his studies religion plays a significant role in the dialectics between the spiritual and the material world. Even in modern urbanized areas in India there are systematic differences in the socio-economic status of members of different religions or even denominations (cf. Milner 1994; Nolan \& Lenski 2006).

\subsubsection{Political Causes of Interreligious Conflict}

Secondly, there can be political causes of conflict between religious groups. In the Indian context Tambiah (1996) points out that conflict often relates to the failure to homogenize and centralize nation-state building projects that pay too little attention to minorities and cultural and/or religious differences between groups. Although Tambiah downplays religious factors by focusing on ethno-nationalist conflict, he explicitly recognizes that religion can play an important role by mixing political and religious ideas. Underpinning nationalism with religious convictions is a case in point, for instance the relation between Indian nationalism and Hinduism. Hinduism is generally seen as a weak candidate for religious conflict, because it lacks both a strong historical sense of itself as a legally organized religion and the traditional religious resources for a fundamentalist movement like a scriptural canon and a theodicy of God acting in history. However, Appleby $(2000,110)$ suggests that, possibly for the same reasons, "Hinduism lends itself powerfully to the cause of nationalist movements constructed around the fluid categories of 'religion' and 'ethnicity'. 
Hindu groups reconstruct religion around nationalist themes to challenge the secular order of the Indian state that threatens the higher castes in traditional India, for example by means of the somewhat vague religio-political idea of Hindutva (cf. Jaffrelot 1996, 80-148). A party like the BJP (Bharatiya Janata Party or Indian People's Party) cites ancient Hindu culture and values as a source of inspiration. Another typically Indian phenomenon is changes in the political picture as a result of religious conversions. In 1981 a group known as dalits, the most oppressed caste in the traditional system, converted to Buddhism, which led to some agitation among Hindu nationalists because of its potential political consequences (cf. Smith 2003; Nussbaum 2007). Appadurai (2006) in particular makes a strong case that decreasing group membership (here among the majority group) can create 'an anxiety of incompleteness' about the sovereignty of the majority in the national polity. 'Anxiety of incompleteness' refers to the idea that minorities "remind these majorities of the small gap which lies between their condition as majority and the horizon of an unsullied national whole, a pure and untainted national ethnos" (Appadurai 2006, 8). This sense of incompleteness can tip over into ethno-nationalism and even ethnocide, which means that minority groups are denied the right to develop and transmit their own language, whether collectively or individually. Violence can erupt in conditions where anxiety of incompleteness is accompanied by feelings of uncertainty about their status as a result of social transformations caused by globalization, or when the majority's access to resources is threatened (Appadurai 2006, 84). In concrete terms: if majority group members (e.g. Hindus) have no access to higher education, uncertainty about their future socio-economic status fuels their anxiety of incompleteness. The relation between politics and access to scarce resources (in terms of education, housing, health care, etc.) supports our decision to include political causes of interreligious conflict in the theoretical framework of realistic group conflict (cf. chapter 1, section 1.2.4).

\subsubsection{Ethnic-cultural Causes of Interreligious Conflict}

Thirdly, conflict between religious groups can have ethnic and cultural dimensions, for instance in the form of an association between religion on the one hand and ethnic or national identity on the other. Religion can trigger conflict by entering into a pact with the ethnic-cultural context. In that case religion functions as a vehicle of ethnic identity construction or a support for nationalism. It reinforces the superior attitude and dominance of certain groups in society (cf. Bruce 2003). Relating national pride (nationalism) to a religious majority can lead to feelings of superiority among this majority, while religious minority groups are seen as inferior. Linking ethnic or national identity to a 
particular religion, in other words, is conducive to religious conflict (cf. Jaffrelot 1996). But the reverse is also possible: religion can expressly rebel against a dominant cultural context. Extremist groups in various religions are characterized by a rebellious attitude towards the modern liberal state (Juergensmeyer 2003,225 ). The liberal (or secular) state refrains to some extent from giving specific moral direction or guidance to its citizens. In the eyes of certain religious movements this creates a moral vacuum or even moral decadence. People blame the leaders of the mainstream of their religion for compromising with liberal values and secular institutions. They believe that this alienates them from their (religious) identity (Darmaputera 1997).

\subsubsection{Religious Causes of Conflict Between Religious Groups}

Finally, some scholars locate religious violence in the dialectical experience of the sacred that represents both an overpowering presence (tremendum) and fascination (fascinans). Because religion is a response to this ambiguous sacred, it contains the potential to heal and to destroy, to love and to hate. A detailed analysis of the phenomenology of the sacred or a theory of religion helps us to understand why there are seeds of violence at the core of religion (Girard 2007; Otto 2004; Wils 2004). Religion motivates people to fight for justice in the name of God. Vanquishing the other is interpreted religiously as a victory over evil. Gaining power can be read as a religious obligation, whereupon preserving that power becomes proof of religious truth. Likewise, the enmity of others can be understood as an offence to the sacred. By using religious codes and metaphors a power struggle can become a 'just war' or even a holy war in the semantics of a cosmic, never ending battle between good and evil. This battle can be deadly serious when it leads to self-sacrifice as an extreme and ultimate expression of religious identity (cf. Juergensmeyer 2003; Steffen 2007).

\subsection{Empirical research}

On the basis of our theoretical framework we questioned Christian, Muslim and Hindu students in Tamil Nadu about their ideas on potential causes of interreligious conflict. In this section we first formulate the research questions, then describe the structure of our newly constructed measuring instrument, and finally present the results of the data analysis.

\subsubsection{Research questions}

Our research questions are the following: 
(1) Which comparative models of causes of interreligious conflict are found among Christian, Muslim and Hindu students once group-specific differences have been ascertained?

(2) Are there significant differences in levels of agreement with causes of interreligious conflict among Christian, Muslim and Hindu students?

(3) Which personal (socio-cultural, socio-economic and socio-religious) characteristics relate to the level of agreement with causes of interreligious conflict among Christian, Muslim and Hindu college students?

\subsubsection{Measuring Instrument}

To answer these research questions we developed a measuring instrument for causes of interreligious conflict. The questionnaire distributed to our respondents deals with four types of causes: socio-economic, political, ethnic-cultural and religious causes of intergroup conflict. We define conflict as "the situation that arises when rival interests can no longer be contained by the structures and processes ordinarily competent to do so" (Lincoln 2003, 74). All items have the same format: " $x$ causes $y$ ", where y refers to the conflict between religious groups and $\mathrm{x}$ is the reason or causal ground. To indicate causation we used verbs like 'encourage' and 'favour'. The socio-economic cause is operationalized in items such as: "The open or silent approval of violence as a means of social change by some religions encourages religious conflict" (item 4). An example of items representing the political cause is: "Intervention by political leaders in religious matters encourages conflict among religions" (item 3 ). The ethnic-cultural cause is represented by items such as: "Linking ethnic or national identity to a particular religion favours religious conflict" (item 11). Specific religious causes are operationalized in similar terms: "Religiously motivated militant or radical groups encourage religious conflict" (item 10). The respondents were asked to indicate whether they agreed with the statements in the items on a four-point Likert scale ranging from 'not at all' (1) to 'strongly' (4). The complete list of items appears in appendix G.

\subsubsection{Empirical Results}

The results of the data analysis provide answers to the three research questions formulated above. We deal with them one by one, presenting the results pertaining to each analysis.

Research question 1: Which comparative models of causes of interreligious conflict emerge among Christian, Muslim and Hindu students once groupspecific differences have been ascertained? 
TABLE 7.1 Factor analysis (PAF, Oblimin rotation), commonalities $\left(h^{2}\right)$, percentage of explained variance, and reliability (Cronbach's alpha) of comparative models of causes of interreligious conflict among Christian, Muslim and Hindu students.

\begin{tabular}{|c|c|c|c|c|}
\hline & Theory & F1 & $\mathrm{F}_{2}$ & $\mathbf{h}^{2}$ \\
\hline $\begin{array}{l}\text { 10. Religiously motivated militant or radical groups } \\
\text { encourage religious conflict. }\end{array}$ & $\mathrm{R}$ & .66 & & .40 \\
\hline $\begin{array}{l}\text { 4. The overt or tacit approval of violence as a means } \\
\text { for social change by some religions encourages reli- } \\
\text { gious conflict. }\end{array}$ & SE & .65 & & .43 \\
\hline $\begin{array}{l}\text { 12. The superiority feeling of some religions encoura- } \\
\text { ges religious conflict. }\end{array}$ & $\mathrm{R}$ & .60 & & .36 \\
\hline $\begin{array}{l}\text { 3. The intervention of political leaders in religious } \\
\text { matters encourages conflict among religions. }\end{array}$ & $\mathrm{P}$ & .58 & & .42 \\
\hline $\begin{array}{l}\text { 11. Linking ethnic or national identity to a particular } \\
\text { religion is conducive to religious conflict. }\end{array}$ & $\mathrm{EC}$ & .58 & & .31 \\
\hline $\begin{array}{l}\text { 5. The belief in the necessity of bloody sacrifices } \\
\text { upheld by some religions inspires religious conflict. }\end{array}$ & $\mathrm{R}$ & .56 & & .32 \\
\hline $\begin{array}{l}\text { 6. The interference of foreign religious leaders in in- } \\
\text { ternal political matters encourages conflict among } \\
\text { religions. }\end{array}$ & $\mathrm{P}$ & .52 & & .27 \\
\hline $\begin{array}{l}\text { 9. Religious conversion that changes the political } \\
\text { equation within a democracy increases conflict } \\
\text { among religions. }\end{array}$ & $\mathrm{P}$ & .48 & & .26 \\
\hline $\begin{array}{l}\text { 1. Affirming one's religion where there are many } \\
\text { religions encourages religious conflict. }\end{array}$ & $\mathrm{R}$ & & .75 & .56 \\
\hline $\begin{array}{l}\text { 2. The human rights awareness promoted by some } \\
\text { religions favours religious conflict. }\end{array}$ & SE & & .40 & .17 \\
\hline Cronbach's alpha & & .81 & .33 & \\
\hline Number of valid cases & & 1811 & 1887 & \\
\hline
\end{tabular}

Scale: In your opinion, to what extent do the following actually favour or encourage conflict among religions? $1=$ not at all; $2=$ a little; $3=$ much; $4=$ =very much.

Explained variance $=35 \% ; \mathrm{F} 1=$ Force-driven religious conflict; $\mathrm{F}_{2}=$ Strength-driven religious conflict.

$\mathrm{SE}$ = socio-economic causes; $\mathrm{P}=$ political causes $; \mathrm{EC}=$ ethnic-cultural causes; $\mathrm{R}=$ religious causes.

To answer this question we used a three-step factor analysis (cf. chapter 1, section 1.7). Table 7.1 presents the results of the factor analysis for all students after filtering out differences between the religious groups.

The structure of these factors does not accord with our theoretical distinctions between the causes of interreligious conflict based on the literature. 
Factor 1 consists of eight items representing all categories of causes (socioeconomic, political, ethnic-cultural and religious). How should we label this factor? Three items relate to religious causes, three to political causes, one to socio-economic and one to ethnic-cultural causes. The item with the highest factor loading concerns religious extremism: "Religiously motivated militant or radical groups encourage religious conflict" (item 10). Item 5 (necessity of bloody sacrifices) also refers to religious extremism. The item with the second highest factor loading (item 4) concerns violence as a means of social change. All items on factor 1 relate to the use of coercive force in interreligious conflict. Item 11 ("Linking ethnic or national identity to a particular religion") and item 12 ("The sense of superiority of some religions") refer to the coercive force of ethnic and religious belonging respectively. Coercive power includes both positive and negative sanctions imposed by power holders on subordinates. It is exercised by an actor who has the capacity to reward or punish others (cf. Etzioni 1961; Baldwin 1971; Molm 1994). This actor can be an individual or a group of individuals like political or religious leaders, but can also refer to ethnic or religious communities that exert social pressure. Force or coercive power implies the imposition of one's will on others, as opposed to free consent or mutual agreement. In the questionnaire items the origin of force lies in religion (i.e. religious extremism), in socio-economic and ethnic causes, or in the overlap of religion and political power. We therefore label the first factor 'forcedriven religious conflict' inasmuch as conflict implies coercive power as a means of achieving the economic, political or socio-cultural goals of religious groups. To avoid misunderstanding, force-driven religious conflict does not measure the respondent's personal willingness to engage in religious conflict. Neither does it measure the extent to which violent behaviour is acceptable to the respondent. It measures to what extent the respondents attribute interreligious conflict to force-driven causes. The reliability of this factor is high $(\alpha .81)$.

Factor 2 consists of two items only. Item 1 falls in the category of religious causes, but refers to affirmation of one's religion and not to religious extremism. Item 2 is in the category of socio-economic causes, but refers to human rights awareness in a religious tradition and not to the pursuit of wealth or power. Affirmation and awareness strengthen people in their religious identity and their search for rights. They clearly lack the dimension of coercion that is present in the first factor. Hence we label the second factor 'strength-driven religious conflict'. Strength is owned and operated by an individual person or we should add - a single group through a positive self-image associated with the convictions and principles the person espouses. Strength refers to the capacity to act and to speak on the basis of one's religious identity. Yet in a plural context this 'strength' can be seen as a source of conflict as well. That is exactly 
what this second factor measures in two items. In the second factor the a correlation between the two items is $r=.38$. This implies that the reliability of the second scale - strength-driven religious conflict - is relatively low ( $\alpha .38)$. Note that factor 1 (force-driven religious conflict) and factor 2 (strength-driven religious conflict) also correlate strongly $(\mathrm{r} .51)$. We elaborate on the labels of both factors in section 7.4.1.

The same two-factor solution emerges when separate factor analyses are conducted for Christian, Muslim and Hindu students in the second step. However, for Muslims items 2 and 9 show low communality (both $\mathrm{h}^{2}=.16$ ). For Hindu students, too, item 2 is slightly problematic $\left(h^{2}=.11\right)$. For purposes of comparison we decided to retain items 2 and 9 in the third step of the analysis described above, but on account of the low psychometric quality of the second scale (strength-driven religious conflict) we excluded it from subsequent analyses.

Next we evaluated the model of force-driven causes of religious conflict for scalar equivalence. Our estimate was based on the ML procedure available on Lisrel 8.8 (Jöreskog \& Sörbom 1996). Models were evaluated by means of JRule (Saris, Satorra \& Van der Veld 2009), a computer program that uses the output of Lisrel and evaluates whether or not constrained parameters are misspecified, taking into account the power of the $\mathrm{ML}$ test. Results show that the scale to measure power-driven religious conflict is scalar invariant $\left(X^{2}=178.41, \mathrm{df}=85\right.$, RMSEA $=0.043$ ) for Christians, Muslims and Hindus. In addition we tested whether factor variances were equal across the groups, which they were $\left(\mathrm{X}^{2}=185.63, \mathrm{df}=89\right.$, RMSEA $\left.=0.043\right)$.

Research question 2: Are there significant differences in levels of agreement with force-driven religious conflict between Christian, Muslim and Hindu students?

On average, students tend to agree strongly $(2.70)$ with the idea of forcedriven religious conflict, with slight, statistically insignificant differences between Muslim, Christian and Hindu students (see Table 7.2). They seem to share an awareness of the use of force to realize group interests as a potential cause of interreligious conflict.

Research question 3: Which personal (socio-cultural, socio-economic and socio-religious) characteristics relate to the causes of interreligious conflict among Christian, Muslim and Hindu college students?

We explain the social location of force-driven religious conflict for each religious group separately. What are the personal characteristics of students who attribute interreligious conflict to force-driven causes? We mention all signifi- 
TABLE 7.2 Levels of agreement (mean and standard deviation) with regard to force-driven religious conflict for Christian, Muslim and Hindu students; and comparison of means between religious groups of respondents (Scheffe's test: F-value: 1.6o; sign.= $.201)$.

\begin{tabular}{lccccc}
\hline & N & Mean & S.d. & Muslims & Hindus \\
\hline Christians & 865 & 2.72 & .68 & \\
Muslims & 252 & 2.64 & .67 & \\
Hindus & 783 & 2.69 & .73 & \\
\hline
\end{tabular}

Scale: $1=$ Not at all, $2=$ A Little; $3=$ Much; $4=$ Very much. There are no significant intergroup differences at $\mathrm{p}<.005$ level.

cant associations, but focus on those which are significant enough to contribute to theory formation, namely moderately strong $(.15<\mathrm{r}<.30)$ or strong $(>.30)$ associations. We describe the significant correlations for each group of students separately (Table 7.3).

Christian students who lived in urbanized areas (.22) and whose mother (.22) and father (.16) obtained higher educational qualifications agree more strongly with force-driven religious conflict. There are also weak associations: female students (mean score 2.77 versus 2.65 for men), non-Tamil speaking students ( 2.89 versus 2.67 for Tamil speakers), those who study the arts or social sciences (2.81 versus 2.68 for natural sciences) and belong to lower castes tend to agree more strongly with the causes of force-driven conflict between religious groups.

What are the personal characteristics of Muslim students who attribute interreligious conflict to force-driven causes? We find a strong association between force-driven conflict and the mother's educational level (.30). Next there are four moderately strong associations. Female Muslim students (mean 2.83 versus 2.48 for men), students living in urbanized areas (.16), those who study the arts or social sciences (mean score 2.90 versus 2.56 for natural sciences) and whose father attained a higher level of education (.27) show relatively more agreement with force-driven conflict.

On average Hindu students who agree more strongly with force-driven religious conflict have parents with higher educational levels ( $\mathrm{r} .27$ for mother's and .24 for father's educational level), have lived most of their lives in urbanized areas (.18), and study the arts and social sciences (mean score 2.88 versus 2.61 for natural sciences), are found among the lower castes (-.15) and have teachers who have less positive influence on their religious socialization $(-.15)$. 
TABLE 7.3 Social location of force-driven religious conflict among Christian, Muslim and Hindu students. Correlations (eta for the nominal variables sex, language and field of specialization; Pearson's $r$ for the other, ordinal variables) between force-driven religious conflict and personal characteristics. ${ }^{1}$

\begin{tabular}{llll}
\hline & Christians & Muslims & Hindus \\
\hline $\begin{array}{lll}\text { Socio-cultural characteristics } \\
\text { Sex }\end{array}$ & $.09^{* *}$ & $.27^{* *}$ & $.09^{* *}$ \\
Language & $.13^{* *}$ & $.16^{* *}$ & \\
Urbanization & $.22^{* *}$ & $.21^{* *}$ & $.18^{* *}$ \\
Field of specialization & $.09^{* *}$ & & $.16^{* *}$ \\
Socio-economic characteristics & & $.30^{* *}$ & $-.15^{* *}$ \\
Caste & $-.12^{* *}$ & $.27^{* *}$ & $.27^{* *}$ \\
$\quad$ Education mother & $.22^{* *}$ & & $.24^{* *}$ \\
Education father & $.16^{* *}$ & & $-.15^{* *}$ \\
Socio-religious characteristics & & & $-.12^{* *}$ \\
Teachers/professors & & & \\
Media & & & \\
\hline
\end{tabular}

Correlations are significant at $\mathrm{p}<.00$ level $\left({ }^{* *}\right)$ or $\mathrm{p}<.05$ level $\left({ }^{*}\right)$.

The mass media, too, have less positive influence on their religious socialization (-.12). Finally, among Hindus women (mean 2.75) agree more strongly with force-driven religious conflict than men (2.61).

\subsection{Findings and Discussion}

\subsubsection{Findings}

We were able to construct a comparative scale of causes of interreligious conflict representing all categories (socio-economic, political, ethnic-cultural and religious causes). The scale has a good reliability coefficient and passed the test of scalar invariance. We labelled this scale 'force-driven religious conflict'. We also managed to construct a second scale, which we labelled 'strength-driven

1 The following characteristics did not show significant correlations for any of the groups of respondents: age, perceived socialization by parents, relatives, friends and religious community. 
religious conflict'. Because of its low reliability we omitted it in further analyses, but we explain our theoretical understanding of both scales in the next section.

There are no significant differences between Christian, Muslim and Hindu students' agreement with force-driven causes of interreligious conflict. All three groups tend to agree strongly with these causes. This means that our student respondents perceive force-driven issues as sources of conflict between religious groups in India. Obviously not all students show the same level of agreement with force-driven causes of interreligious conflict. The level correlates with their socio-cultural, socio-economic and socio-religious personal characteristics.

Socio-cultural characteristics generally produce the same picture for all religious groups: students who lived in urbanized areas and students in faculties of arts and social sciences agree more strongly with force-driven conflict. While in urban areas religious diversity is more clearly visible and relationships are more anonymous, they are not necessarily characterized by more interreligious conflict than rural areas. That students in the arts and social sciences are more inclined to attribute interreligious conflict to force-driven issues could be explained by the fact that they are better informed about societal questions than students of the natural sciences. Among Muslims gender also has a moderately strong association with force-driven religious conflict, female students tending to agree strongly and male students to agree less with force-driven religious conflict. Christian and Hindu female students show stronger agreement than men, but here the association between gender and force-driven conflict is weak.

Why is this association relatively strong among Muslim students? Can we attribute it to gender differences among Muslims in India? While India in general is not particularly female-friendly, Muslim women experience even more social restrictions than Hindu and Christian women. Although the southern state of Tamil Nadu is less gender restrictive than northern conservative states (e.g. Uttar Pradesh), there are differences between the religious groups all over the country (cf. Dyson \& Moore 1983). Census data do not offer much religiously related socio-economic information, but some data indicate differences between Christian, Muslim and Hindu women in this regard. Female educational levels differ according to religion. Figures of illiteracy in rural India are almost identical for Muslim ( $76 \%$ ) and Hindu (75\%) women, as opposed to $43 \%$ for Christian women. But in urban India the cross-religious differences are more significant, $60 \%$ of Muslim women being illiterate as opposed to $42 \%$ of Hindu and $23 \%$ of Christian women. It would be unfair, however, to depict Islam as female-unfriendly on the strength of (il)literacy figures. Overall cross-religious 
differences are much bigger than differences between the sexes. Male illiteracy in urban India is also highest among Muslims ( $42 \%)$, followed by Hindus $(25 \%)$ and Christians (19\%) (Minority Rights Group International 1999, 24ff). Nevertheless "Muslim women in urban India are much worse off than their rural counterparts, not only in terms of their overall educational status as citizens of India, but also in terms of their relatively poor educational status when compared to Hindu or Christian women" (Minority Rights Group International 1999, 26). Clearer cross-religious differences based on gender are manifested in work participation rates. The National Sample Survey Organisation (1997), for instance, reports a major gap between the work participation rates of Muslim women on the one hand and Hindu and Christian women on the other, Muslim women having the lowest participation rate in all categories of paid work. The difference between women's and men's work participation is also biggest among Muslims compared to Hindus and Christians. Earlier studies have shown higher levels of women's seclusion among Muslims compared to nonMuslims (Morgan et al. 2002). Ghuman et al. (2006), for instance, measured women's autonomy by asking couples (women and men separately) whether a wife has to ask permission to go anywhere outside the house or compound, to the local health clinic or to the local market. However odd this question may seem, the findings show cross-religious differences in women's autonomy in the perceptions of both women and men, Muslim women being perceived as least autonomous. There were also cross-religious differences with regard to disagreement between women's and men's perceptions of the wife's autonomy. In general men tend to attribute more power to the wife than she does to herself, because husbands may wish to present themselves in a favourable light (Meyer \& Lewis 1976) and/or wives may be socialized to be more passive and understate their own power (Olson \& Rabunsky 1972). But the differences between women's and men's perceptions of the wife's autonomy are biggest among Muslims (Ghuman et al. 2006, 25). All this proves that gender issues are far more important in India than in Western contexts. Further research into the mediation and moderation of religion in gender differences is essential.

Among all religious groups socio-economic characteristics have strong associations with force-driven religious conflict. More specifically, mother's and father's education correlates positively with attribution of interreligious conflict to force-driven causes, while caste (among Christians and Hindus) has a weak negative association with force-driven interreligious conflict. These associations seem to reveal opposing mechanisms in the relationship between socio-economic status and the attribution of force-driven causes to interreligious conflict. On the one hand respondents whose parents' educational level is relatively high agree more strongly with force-driven causes of interreligious 
conflict. Are students from more educated families better informed about the socio-economic, political and ethnic-cultural background to conflict between religious groups? On the other hand, respondents from relatively higher castes (i.e. upper socio-economic strata) agree less with force-driven causes of interreligious conflict. It seems that those who have more to lose perceive more force-driven sources of interreligious conflict. These opposing relationships of socio-economic characteristics with force-driven religious conflict accord with inconclusive research findings regarding the effects of socio-economic status on prejudice, discrimination and hostility towards others (Brondolo et al. 2009; Carter et al. 2011; Floyd \& Gramann, 1995; Portes 1984; Stephan \& Stephan 2000). Educational level is often a strong determinant of less prejudice toward out-groups (Hello et al. 2002), but the degree to which the out-group is perceived as a threat, whether as a 'real' threat in respect of material resources or a 'symbolic' threat in respect of intangible resources such as values or culture, is associated with greater prejudice (cf. Hello et al. 2002).

Socio-religious characteristics are negatively associated with the attribution of interreligious conflict to force-driven conflict among Hindu students only. Hindu students agree more strongly with force-driven religious conflict if their teachers/professors and the media have a less positive influence on their religiosity. Teachers/professors and the media are secondary (i.e. societal) socializing agents. Agents of primary socialization (parents, relatives and friends) apparently do not make a difference. Why do only secondary socializing agents relate to force-driven religious conflict? And why only for Hindu students? As the majority group in India, Hindu students generally are the majority in educational institutions, also in Protestant or Catholic schools - a large part of our sample - where the majority of professors are Christian. If these professors have less positive influence on Hindus' understanding and practice of their own religion, interreligious conflict is more likely to be recognized and attributed to force-driven causes. And if the influence of the prominent mass media on one's own religiosity is considered less positive, it might make one feel threatened by other religious traditions, thus leading to agreement with forcedriven causes of interreligious conflict. Both mechanisms could point the way to explain our finding, but further research is necessary to confirm this interpretation.

\subsubsection{Discussion}

In this section we discuss two issues. First, we explain theoretically the two kinds of attribution of interreligious conflict that we have established empirically, namely force-driven and strength-driven religious conflict. We do so with reference to Hannah Arendt's philosophical analysis of power in the political 
domain. Second, we evaluate the possible use of violence which can lead to suffering and evil inflicted on others. Comparative research should not stop with a description of findings, but also needs to evaluate these findings from a normative perspective (cf. section 2.7). We introduce two normative perspectives in this section. The first is Hannah Arendt's theory of action, which reflects on the plurality of actors in the public domain and on human freedom. The second is Paul Ricœur's philosophical thought on the problem of evil in relation to human action and suffering. Evil can be regarded as the dark, incomprehensible side of violence in both its active and its passive form. Different forms of violence in society should never be evaluated in a simplistic scheme of good (people) versus bad (people). Normative evaluation of good and bad is often more complex and incomprehensible when viewed from the perspective of evil. We think Arendt and Ricœur offer fruitful normative perspectives on conflict, (potential) violence and evil.

\section{Towards a Theory of Force-Driven and Strength-Driven Interreligious Conflict}

In this chapter we have distinguished empirically between what we labelled force-driven religious conflict and strength-driven religious conflict. What theoretical background underpins these labels? We think Hannah Arendt provides a basis, specifically in her political theory and action theory developed in The human condition (Arendt 1958 11 1998) and her reflections on the relation between politics and power in On violence (Arendt 1970). We analyse the distinction between power, force and strength. Before we do so, we locate power in the framework of political freedom, which is the focus of Arendt's political theory. Arendt evaluates the political realm according to the normative criterion of preserving agents' freedom of action and speech, especially in relation to the plurality of people in the public domain (cf. Dossa 1989; Keenan 1994).

At the heart of Arendt's political theory is the idea that personhood is constituted by the power to act and to speak. If one robs people of this power, they lose their personhood. And the power to act and to speak can be taken away. It only exists potentially and is not necessarily or always present. Only in actualizing the potential to act do people gain personhood. The idea of persons living together eo ipso implies concerted action. According to Arendt $(1998,198)$ the political realm (or polis) is "the organization of people as it arises out of acting and speaking together, and its true space lies between living together for this purpose". This 'space of appearance' - as Arendt calls it - is realized when different people come together and can act and speak in complete freedom. It is a space where actions may establish preliminary relationships and where words can reveal intentions and disclose developing realities. In the space of 
appearance different people meet each other in freedom. There "I appear to others as others appear to me" (Arendt 1998, 198). Hence the space of appearance is marked by plurality and freedom. Plurality means that people with different opinions, feelings, longings, dreams, et cetera are able to act together and speak to each other. Although we are different, there is a basic equality that makes it possible to live together. In plurality equality and distinctness are combined in such a way that it becomes possible to live together. "We are all the same, that is, human, in such a way that nobody is ever the same as anyone else who ever lived, lives, or will live" (Arendt 1998, 7f.; cf. Habermas 1977, 7). Freedom means that people have the opportunity to take the initiative and start something new. The fact that humankind is capable of action and speech means that the unexpected can be expected. Free people are able to do the unanticipated and to realize what is improbable (Arendt 1998, 177f.; cf. Habermas 1977,8$)$.

The space of appearance antedates and is presumed in all formal constitutions of the public domain. Whatever form of government or legal structure is chosen to organize the public domain, it is only legitimate if that space is recognized. In other words: the space of appearance in which people gather can be seen as the first manifestation of political freedom; but it is extremely fragile, hardly more than a potentiality. The potential still has to be realized. What brings the public space of appearance to life? Arendt $(1998,200)$ answers this question as follows: "Power is what keeps the public realm, the potential space of appearance between acting and speaking men, in existence." Power is generated when people come together and act in concert (Arendt 1970, 52). It is not a property of individuals but belongs to a group of people and remains in existence only as long as the group keeps together (Arendt 1970, 44). Power entails a plurality of actors joining together in freedom for some common political purpose. It is generated by people when they act together. But here, too, the problem of continuity arises. What guarantee do we have that it will still be actualized in the future? What gives duration to the power of concerted action based on freedom that was there in the beginning? The human force that can create this continuity is mutual promise. Mutual promise keeps power alive when the space of appearance is threatened. Promising is an act that remembers itself at the very moment when the promise is made. "By holding actors together into the indefinite future, promising transforms freedom from the simple possibility of new beginnings into 'worldly' political freedom" (Keenan $1994,305)$. Put differently, a mutual promise or contract can serve as a foundation for the political realm while remaining true to the logic of freedom. The promise is a speech-act way of remembering itself; it institutionalizes the power of acting in concert by promising itself (Keenan 1994, 307). Yet it retains the 
logic of freedom which manifests itself in a twofold unpredictability in the act of promising: firstly "man's inability to rely upon himself or to have complete faith in himself (which is the same thing) is the price human beings pay for freedom; and [secondly] the impossibility of remaining unique masters of what they do, of knowing its consequences and relying upon the future, is the price they pay for plurality" (Arendt 1998, 244).

Can the institutionalization of promise provide the foundation for the political realm that power could not provide? The twofold unpredictability indicates that it cannot. In her later publications Arendt tries to 'solve' this problem by introducing the category of authority. Scholars strongly agree that Arendt tries to combine the logic of freedom with the authority of foundation (Habermas 1977; Keenan 1994). There is a potential for conflict and violence in the interpretation of political foundations. "This tear within the heart of the political realm lies in the act of decision itself, divided as it is between the freedom of reconstituting the political realm by redefining the promise and the violence of imposing that definition in ways that all do not accept and that exclude other possible communities and other possible futures" (Keenan 1994, 318). In the face of a plurality of opinions political action tends to forget the freedom that makes it possible. Arendt rightly reminds us that political institutions are not born out of conflict but should be based on recognition. The legitimacy of power can only rest on the freedom of people acting together. But this idea of political power needs to be distinguished from the exercise of power or rule (Habermas 1977, 17). The latter implies "that men can lawfully and politically live together only when some are entitled to command and the others forced to obey" (Arendt 1998, 222).

Now that we have formulated the notion of power in Arendt's political theory we can distinguish it from force and strength. Force is characterized by violent action (Arendt 1998, 203). It exercises coercion in a social sphere and involves manifest or latent violence. Violence creates a situation in which people lose their capacity to act and speak in freedom. But while violence can destroy power, it can never be a substitute for it. Force always manifests itself in combination with powerlessness, as in tyrannical government where one person has the monopoly of violence. Force contradicts the essential human conditions of plurality (acting and speaking together) and freedom (initiative), which are essential components of any legitimate political organization. But force is not confined to the political domain. It can also take the form of economic force when the haves pressurize the have-nots. Or it can have an ethniccultural dimension when high status groups dominate low status groups. One also thinks of religious groups who force their ideas on others and thereby render members of other religious groups powerless. Unlike power, force leads to 
a win-lose situation (Arendt 1970). While power can be divided without diminishing it, force leads to an increase of the potentiality to act for some and a decrease of that potentiality for others. That is why force and conflict go together, just as power and peaceful coexistence belong together. Among religious extremist groups the use of violence is obvious. But other developments may also disrupt the balanced space of appearance between different individuals or groups. Changes in the relative size of groups (in terms of minority and majority), for instance, can influence the fragile power balance. Or linking national identity with religious belonging (as in Hindutva) can lead to a diminished potentiality to act and speak among minority groups.

Strength shares with force the idea of the capacity to act and speak. Strength is "nature's gift to the individual which cannot be shared with others, [and] can cope with violence more successfully than with power - either heroically, by consenting to fight and die, or stoically, by accepting suffering and challenging all affliction through self-sufficiency and withdrawal from the world" (Arendt $1998,203)$. Strength is possessed by an individual person or - we would add - a single group via a positive self-image associated with the convictions and principles the person or group stands for. It does not need a social sphere or a space of appearance in which different people act and speak. The strength of individuals' convictions or their charismatic personalities make them strong leaders who are able to persuade others. Strength, too, is not a substitute for power but, unlike force, it does not imply powerlessness. With strength the person's integrity and the possibility to act remain intact. When a person (or group) affirms her (its) religious identity in a plural context, it is an expression of strength. It does not create a ground for living together, but the strength of the person or group resists the idea of powerlessness. This happens, for instance, when a religious group demonstrates against laws or regulations which limit its freedom of expression or hamper its culture in some way. Suppose that individuals participate in demonstrations even if they run the risk of arrest or harassment. In that case demonstrating clearly expresses strength, although it does not create a ground for living together.

How does this analytical distinction of Arendt's help us to label the two kinds of attribution of interreligious conflict that we have identified empirically? The causes in the items of the first scale all imply the use of some kind of force against members of other religious groups. They hint at actions that take away other people's power to act or speak. In force-driven religious conflict items refer directly or indirectly to violence, either socio-economically motivated (item 4: overt or tacit approval of violence as a means of social change), politically motivated (item 3 : intervention by political leaders in religious matters encourages conflict), related to ethnic-cultural issues (item 11: linking eth- 
nic or national identity to a particular religion is conducive to religious conflict) or in regard to religious issues (item 10: religiously motivated militant or radical groups encourage conflict). In all cases increasing the power of one group coincides with making other groups (more) powerless. The second scale consists of two items which do not result in disempowering the other, but neither do they aim at establishing a space of appearance in which people act in concert. The two items in strength-driven religious conflict focus on strengthening one's religion, both in terms of human rights awareness and the affirmation of one's own religion in a multi-religious context. The actions formulated in these two items are not direct sources of conflict. On the other hand, it is possible to perceive religious identification as contributing to conflict. When awareness of human rights is promoted in a context where these rights are violated by others it can lead to (further) conflict. This also applies when one's own religion is affirmed in a plural context where a majority religion feels threatened by the presence of other religious communities. These items - respectively on awareness and affirmation - are expressions of strength. Individuals or particular groups show their willingness to act and speak even if it may have negative consequences for them. The connection between awareness and affirmation on the one hand and potential conflict on the other justifies this interpretation.

However, we stress the limitations of our research (in terms of metric qualities) in the case of strength-driven religious conflict. Further research is necessary to test whether this concept holds good, along with the concept of force-driven conflict. We also recommend future research to determine whether force-driven religious conflict and strength-driven religious conflict can be distinguished from the power to act in concert. Nonetheless our findings show that Arendt's conceptual distinctions can be fruitful in empirical research into interreligious conflict. They clearly indicate that creating a space of acting and speaking together in a context of plurality is a crucial problem in the polis.

\section{Evaluation of Force-Driven Religious Conflict}

The second issue is normative evaluation of force-driven conflict. We base this evaluative perspective on the philosophy of Paul Ricœur, a representative of what we labelled the pluralist-deliberative route (see section 2.7). Ricœur pursued ever new avenues to fathom the moral issue of evil: via the human will, via narratives of the suffering person, and finally through his reflections on the difficulty of memory and the impossibility of forgiveness. Each of these angles on the moral issue of evil opens up another perspective from which to evaluate force-driven conflict. We structure Ricœur's moral deliberations into three phases. 
(1) The problem of evil first appears in Ricœur's work in the context of a hermeneutics of the symbolism of evil. To understand this first phase of his thinking about evil one has to connect it with his reflection on the phenomenology of the will. Human free will intrinsically creates the possibility of evil. Human beings not only cause evil as an unintended effect, but are capable of intentionally willing what is wrong. Evil falls under the heading of free will (Gisel 2007; Boey 2008, 30f). The intention to do wrong is connected with a disproportion in free will between infinite desire and finite reality. If the will does not accept the finitude of the realization of human desire (e.g. the desire for power, possessions and recognition), the will can take the form of something evil. Evil is the manifestation of absolute free will, such as absolute power or possession of everything which disregards others' equal right to power and recognition.

Because of free will humans are susceptible to wrongdoing. But the potential to do evil is not yet the reality of evil itself. Why do human beings shift from innocence to guilt, from the possibility of evil to its actualization and avowal? Why do they do evil? The answer to this question does not lie in a description of human volition (Gisel 2007; Kearney 2006, 198). Evil is connected with the enigma of sudden appearance: it need not be enacted, but it suddenly appears. This enigmatic character of evil precludes a straightforward rational analysis of human volition. To understand the shift from possibility to actuality we must turn to the symbolism of evil. Through a hermeneutics of signs we gain access to evil. Even then evil remains an enigma. It can never be fully explained because signs, symbols and myths should not be taken literally. Signs only indicate reality. Myths never become rational knowledge. And symbols enable us to think of what cannot be accessed otherwise (Ricœur 1967, 15). Literal interpretation of religious myths or reification of religious symbols actually corrupts religion. When this happens (e.g. in fundamentalism) the fragile interpretation of symbols is wrongfully turned into absolute knowledge. "When any individual, sect, or denomination presents itself as possessing the exclusive or definitive understanding of good and evil, when 'evil' is used as a blanket term of condemnation to advance a dubious political agenda, then there is a corruption of religion" (Bernstein 2007, 119).

What insight does Ricœur's (1967) hermeneutic detour via the symbolism of evil afford into the shift from the possibility of evil to its actualization? And what is the possible role of religion in the regeneration of free will (Ricœur $1995)$ ? With regard to the shift from possibility to actualization of evil, we note two ideas. The first is a distinction in the origin of evil, namely a deterministic and an anthropological account (Kearney 2006, 198ff; cf. Ricœur 1967, 156ff). In a deterministic account evil emanates from external forces (e.g. the symbolism 
of defilement). In an anthropological account evil originates in the self (e.g. the guilty self recognizes its own 'servile will'). Moral responsibility is only possible when the blame is not projected onto circumstances, others or even the Other. Moral consciousness is a "bad choice that binds itself" (Ricœur 1967, 156) and only emerges when we acknowledge wrong as our own fault. The second idea is the disruption of the borderline between perpetrator and victim. On the one hand there is evil which makes another person suffer. On the other hand people feel they are victims of the wickedness and violence of others. A hermeneutic interpretation of the symbolism of evil disrupts this clear-cut borderline between perpetrator and victim, and thereby turns evil into a confused experience. Myth makes us aware that there is a strange passivity in doing evil. From the side of the perpetrator people might feel themselves victims even though they are guilty (e.g. through the past history of evil in which they are implicated). From the side of the victim there might be a strange awareness of receiving punishment that is deserved. This awareness can find its source in the idea that all suffering is deserved, for example because of some personal or collective fault (Ricœur 2007, 38). This reflection makes us realize that the boundaries between perpetrator and victim in force-driven conflict are not always clear. They are messy, blurred and confused. In complex intergroup conflict we need to be suspicious of simplistic pictures that present one group (or individual group member) as purely a perpetrator and another as an unadulterated victim.

What is the possible role of religion in the regeneration of free will? How can we ensure that our free will is directed to the good? This assurance cannot come from free will itself. If it does not originate from our free will, it eludes our autonomy. But this leaves us with a paradox, because we need to be sure that the capacity of free will to act out of duty remains intact. The actuality of doing evil reveals a paradox at the heart of our human freedom: both lost and to be recovered. "This uncommon situation opens, moreover, a place for religion that is distinct from that of morality - religion, according to Kant, possessing no theme other than the regeneration of freedom, that is, restoring to freedom the control over it of the good principle" (Ricœur 1992, 216; cf. Sterkens 2001, 227-231; Dupont 2010, 168).

The recovery of freedom demands some help from outside (beyond our autonomy), which at the same time should not destroy our autonomy but restore it. On the one hand, without a gift no change of heart would be possible. On the other hand the bestowal of a gift cannot take away the responsibility of the will. "What remains is that the will turns toward this good coming from elsewhere than its disposition toward good that has not abolished its tendency toward evil" (Ricœur 1995, 86). In philosophical thought this paradox of our 
attempt to do good and the externality of a gift has the structure of hope. It consists in the idea that reception of the gift also entails a command to mobilize our capacity to do good. We hope that what we receive is in fact a change of heart. On the other hand, resorting to radical confession of evil in the depths of the will also means opening oneself to receive the gift. Hoping for the gift that will restore our capacity to do good restores our capacity to do good. In the depths of our free will we cannot distinguish between our own effort and the alterity of the gift (Ricœur 1995, 87). In the face of doing evil we hope to be restored to doing good and at the same time we hope that this will be given to us. "Perhaps the philosopher as philosopher has to admit that one does not know and cannot say whether this Other, the source of the injunction, is another person whom I can look in the face or who can stare at me, or my ancestors for whom there is no representation, to so great an extent does my debt to them constitute my very self, or God - living God, absent God - or empty place. With this aporia of the Other, philosophical discourse comes to an end" (Ricœur 1992, 355).

(2) In a second phase Ricœur looks at the problem of evil from a different angle: that of the experience of suffering and the lamentation of the suffering person. His focus shifts from the problem of origin ('why?) to the enigma of suffering ('why me?). The lamentation of the sufferer, who cries out that the violence inflicted upon him is undeserved and unjust, resists any attempt at understanding. By focusing on the lamentation of the sufferer Ricœur addresses the problem of the effects of evil instead of representations of its origin. It is a shift from speculative thought about the aporia of evil to the experiential fact of this aporia. His major publication in this period is a lecture given in Lausanne in 1985 (Ricœur 2007). In this lecture Ricœur traces the path that speculative thought has taken in Western thinking about the aporia of evil. $\mathrm{He}$ understands this Western trajectory as one of refinement: how can speculative thought reflect the experience of evil in action and suffering? We will not follow the entire trajectory, as it is beyond the scope of this book. The core of Ricœur's argument is that we have to try to understand evil, but in the process we should preserve the aporia. We need a reflective moral view of evil, but should not ignore the protest against unjust suffering.

A strictly moral view of evil tends to disregard the aporia attested in experiences of suffering. Speculative thinking on evil as in theodicy arguments (e.g. Leibniz, Hegel) included all forms of evil under the heading of metaphysical evil, in which the tragic and the logical coincide: something has to die for something greater to be born (Ricœur 2007, 54). Although these speculative thoughts display great philosophical refinement, they should be criticized insofar as they neglect the aporia of evil and the victims of history who have 
been marginalized. We need to think about human suffering as evil in order to understand that some questions and answers about evil are 'wrong'. In a sense one could say that our thinking acts like a filter of what not to think. Ricœur concludes that the aporia in human understanding of evil deserves the final word. What is more, it is as a result of our thinking that we come to see evil as aporetic. Ultimately evil cannot to be conquered by thinking. "It is this aporia that action and spirituality are called to give, not a solution, but a response aimed at making the aporia productive; in other words, at continuing the work of thought in the key of acting and feeling" (Ricœur 2007, 65-66).

What response makes the aporia productive? The response of action is its focus on what needs to be done to combat evil. "Every action, whether ethical or political, which diminishes the quantity of violence exercised by some against others diminishes the level of suffering in the world" (Ricœur 2007, 66). Yet we must be aware that a practical response will not resolve all problems of evil. It will not solve the problem of innocent victims of violence, nor will it solve suffering not caused by unjust action of someone towards others (e.g. natural catastrophes or illness). In other words, the practical answer does not answer the question: 'Why me?' Although we must act when faced with experiences of suffering, practical answers do not silence the question 'Why me?' Ricœur then cites the human capacity for feeling as a third response to the enigma of suffering. Here Ricœur $(2007,68)$ speaks about a spiritual transformation in the work of mourning: a transformation which starts with acceptance of ignorance ('I don't know why'), accepts the impatience of the sufferer ('How long, oh Lord?'), separates reasons for belief in God from explanations of the origin of suffering, ending in complete renunciation of the desires which engender the lamentation: the desire to be rewarded for one's virtuousness, and to be spared suffering in order to break out of the cycle of retribution in which the lament remains captive (Ricœur 2007, 71-72). What is needed emotionally is a loosening of all bonds that make us experience the loss of a beloved object as the loss of ourselves (Ricœur 2007, 78). We can detach ourselves emotionally from all desires connected with the question 'Why me?' In this way we reach peace of mind, which is the effect of wisdom.

Ricœur's reflections on evil from the perspective of the sufferer offer some guidelines for a moral evaluation of causes of interreligious conflict. Firstly, we need to be aware of the different ideas which religions proffer on evil and human suffering. Some ideas are more helpful to understand evil and also leave the aporia of evil open. Secondly, whatever attributions we make with regard to conflict, they will never resolve the aporia in our understanding of conflict. It is difficult to fully understand conflict, let alone violent conflict. There is always a temptation to reductionism in empirical research, including empirical 
research into the causes of interreligious conflict. We cannot claim to have explained the intentions of believers towards acts of violence. From a normative point of view we have to be aware that in the experience of the sufferer the aporia of evil has the final word. No explanation will answer the question 'Why me?' Thirdly, thinking needs to find a response in action to diminish the suffering inflicted by conflict. An academic study of causes of interreligious conflict cannot restrict itself to description or explanation. Our understanding of conflict should lead to reflection on actions which can diminish suffering (see chapter 9). Finally, we should not to forget that neither thinking nor action can resolve the aporia of evil. This research focuses on Tamil Nadu students' ideas on interreligious conflict. But one can also imagine research into the experience of victims of violence. There is always an ethical responsibility for the research subjects. On the basis of Ricœur's analysis, the core of this ethical responsibility is to help victims to deal emotionally with the aporia of suffering or to help them with the unanswerable question: 'Why me?'

(3) In a third phase Ricœur $(1995,289-292)$ shifts his focus to the emancipatory function of narration in memorizing historic events of evil. Two issues are relevant to our research: remembrance of suffering and forgiveness of the perpetrators.

Firstly, why should we remember the victims of violence in history? Remembering is a moral duty in the sense of a debt owed to victims. Remembering the specific horror of violence prevents people from being victimized twice. Our memory of past incidences of evil should respect the uniqueness of the events. The power to singularize in narration prevents our comprehension of a specific event from becoming inhuman in the sense that it could even make the event necessary, for instance if the conflict is attributed exclusively to economic, political or cultural causes (Ricœur 1995, 290). Memory of suffering is not neutral: it identifies victims as victims and perpetrators as perpetrators. From a moral point of view, victims and perpetrators of violence are not on a par. The perpetrators are guilty, while the victims are suffering because of violence inflicted on them. Although narration is an act of imagination, we should never forget the reality of what happened in history. Our memory of suffering is not just fiction, although it comes to us in the shape of imagination. A narration is a work of fiction which can help us see and feel the past as if we were present in the event itself (Kearney 2006, 207). At the same time this distinction between narrative imagination and historical facts should prevent us from seeing a narrative account of past events as a literal description: all remembrance is a battlefield of interpretations. Finally, our memory of suffering should also express the impatience of hope experienced by the victims. Re- 
membering should not deter the victim from hoping for a better future (Ricœur 1995, 291; Boey 2008, 45).

The second issue is that of forgiveness or memory that can heal. Genuine forgiveness involves not simply forgetting past events but of viewing them differently in a way that emancipates them from the deterministic clutch of violent obsession and revenge (Kearney 2006, 210). Forgiveness breaks the cycle of violence by giving a future to the past. This does not mean that the harm can be undone: the perpetrator of violence will always be the person who made others suffer. At the same time the call for forgiveness is experienced as impossible. How could one sever the harm from the perpetrator? It is not only the results of evil which are an aporia; the act of forgiving, too, is hidden in the abyss of our understanding. We cannot expect victims of violence to forgive the perpetrator. But it happens: this impossible act of forgiveness can happen. By what power can it happen other than the primordial affirmation that every human being (including the perpetrator) is destined for goodness? The person who repents and the person who forgives disconnect the criminal from his or her crime on the strength of the belief that the good in humankind is more ultimate and unconditional than all the evil we can imagine (Boey 2008, 92). According to Ricœur this is also what religions are called to awaken in their followers in situations of violence.

What is useful in these reflections for our consideration of the causes of interreligious conflict from an ethical perspective? The first benefit is singularization of events. We should not write about interreligious conflict as if it does (or did) not happen in a real place to real people. Conflict refers to historical events which need to be remembered. Our studies should give the sufferers a voice, otherwise they are victimized twice. One way to do this is to put research into causes of interreligious conflict in a historical framework. Secondly, our analyses and reflections should attest the belief that all parties (victim and perpetrator) are destined for the good. Good has the final word, not evil. We should also criticize the convictions of any religion that contradict this moral axiom, such as that some people or some groups represent absolute evil (Bernstein 2005). 